\title{
KOMPETENSI SUMBER DAYA MANUSIA TERHADAP KUALITAS PELAYANAN PUBLIK DI KANTOR DESA MADDENRA KECAMATAN KULO KABUPATEN SIDENRENG RAPPANG
}

\author{
1)Fitri Handayani, ${ }^{2}$ Erfina, ${ }^{3)}$ Pratiwi Ramlan \\ Fakultas IImu Sosial dan IImu Politik Universitas Muhammadiyah Sidenreng Rappang \\ fitriihandayani43162032.1b@gmail.com
}

\begin{abstract}
Abstrak
Kompetensi sumber daya manusia terhadap kualitas pelayanan publik di Kantor Desa Maddenra Kecamatan Kulo Kabupaten Sidenreng Rappang dan untuk mengetahui faktor-faktor yang memengaruhi kompetensi sumber daya manusia di Kantor Desa Maddenra Kecamatan Kulo Kabupaten Sidenreng Rappang. Populasi penelitian ini adalah sebanyak 2.095 orang. Sampel sebanyak 95 orang. Tehnik penarikan Sampel yang digunakan adalah PUrpossive Sampling. Tipe penelitian ini adalah deskriptif kuantitatif. Tehnik pengumpulan data yang digunakan adalah observasi, wawancara, kuesioner, dan studi pustaka. Tehnik analisis data yang digunakan adalah statistic deskriptif dan dengan bantuan aplikasi SPSS versi 21. Hasil penelitian menunjukkan bahwa Kompetensi Sumber Daya Manusia di Kantor Desa Maddenra dengan persentase $58,16 \%$ berada pada kategori kurang baik. Kualitas Pelayanan Publik di Kantor Desa Maddenra dengan persentase $58,30 \%$ berada pada kategori kurang baik. Berdasarkan nilai t hitung $>t$ tabel atau 9,855 $>1,989$ $\mathrm{HO}$ ditolak yang artinya Kompetensi Sumber Daya Manusia berpengaruh signifikan terhadap Kualitas Pelayanan Publik di Kantor Desa Maddenra Kecamatan Kulo Kabupaten Sidenreng Rappang dengan Sumbangan Persentase pengaruh sebesar 51,1\%. Faktor-faktor yang memengaruhi Kompetensi Sumber Daya Manusia: a. Faktor Internal: 1) Pegawai dalam peningkatan kemampuan pelayanan $58 \%$. 2) Kemampuan pegawai dalam mengantisipasi keluhan masyarakat $59 \%$. 3) Peningkatan Pegawai dalam penggunaan komputer 56\%. b. Faktor eksternal: 1) Sikap Pemerintahan terhadap dukungan sumber daya manusia 59\%. 2) keterlibatan masyarakat dalam peningkatan pelayanan $57 \% 3$ ) pelatihan pegawai untuk mendukung pengembangan tekhnologi $51 \%$. Berdasarkan uraian di atas, maka dapat disimpulkan bahwa faktor-faktor yang memengaruhi Kompetensi Sumber Daya Manusia di Kantor Desa Maddenra dengan persentase $56,67 \%$ berada pada kategori kurang baik.
\end{abstract}

Kata Kunci : Kompetensi Sumber Daya Manusia dan Kualitas Pelayanan Publik

\section{Abstract}

Competence of human resources on the quality of public services in the Maddenra Village Office, Kulo District, Sidenreng Rappang Regency and to determine the factors that influence human resource competence in the Maddenra Village Office, Kulo District, Sidenreng Rappang Regency. The population of this study was 2,095 people. Samples were 95 people. The sampling technique used is Purpossive Sampling. This type of research is quantitative descriptive. Data collection techniques used were observation, interviews, questionnaires and literature study. The data analysis technique used is descriptive statistics and with the help of SPSS application version 21. The results showed that the Human Resources Competence at the Maddenra Village Office with a percentage of $58.16 \%$ was in the unfavorable category. The quality of public services at the Maddenra Village Office with a percentage of $58.30 \%$ is in the poor category. Based on the value of $t$ count $>t$ table or 9,855> 1,989, then HO is rejected, it means that Human Resources Competence has a significant effect on the Quality of Public Services in the Maddenra Village Office, Kulo District, Sidenreng Rappang Regency with a percentage contribution of $51.1 \%$ influence. Factors that Influence Human Resources Competence: a. Internal factors: 1) Employees in improving service capability 58\%. 2) The ability of employees to anticipate public complaints 59\%. 3) Increased employee use of computers $56 \%$. b. External factors: 1) Government attitudes towards human resource support 59\%. 2) Community involvement in improving services $57 \%$. 3) employee training to support technology development $51 \%$. Based on the description above, it can be concluded that the factors that influence the Competency of Human Resources in the Office of Maddenra Village with a percentage of $56.67 \%$ are in the unfavorable category.

Keywords : Competence of Human Resources and Quality of Public Services

PRAJA $\mid$ Volume 8| Nomor 3| Edisi Oktober 2020 


\section{A. PENDAHULUAN}

Berdasarkan

atas Permenpan (Peraturan Menteri Pandayagunan Aparatur Negara) Nomor 15 tahun 2014, pasal 1 tentang pedoman Standar Pelayanan, diharapkan setiap penyelenggaraan pelayanan publik wajib meneetapkan Standar Pelayanan Publik dalam melakukan layanan kepada masyarakat, sehingga masyarakat lebih dapat memahami prosedur pelayanan, dalam standar pelayanan prima, seorang petugas pelayanan harus memiliki kompetensi di bidangnya, sehingga mutlak seorang pegawai harus memiliki kemampuan/ keahlian. Kompetensi merupakan kemampuan individu yang melakukan pekerjaan serta mengambil keputusan sesuai dengan peranannya dalam organisasi yang sesuai dengan keahlian, pengetahuan, dan kemampuan yang dimilki. pada bulan November 2019 yang dilakukan dan beberapa informasi yang diperoleh oleh peneliti,ditemukan fakta bahwa Kemampuan pegawai masih redndah dalam hal pemberian layanan.

Salah satu faktor utamanya adalah aktor pemberi pelayanan yaitu pegawai Kantor Desa Maddenra, dalam hal ini kompetensi manusia yang ada dalam melakukan pekerjaannya, seperti prosedur pelayanan terkadang berbelit-belit, dalam pelayanan surat permohonan Kartu Keluarga dan Surat Pengantar KTP, akte kelahiran serta surat lainnnya, hal tersebut terjadi karena aparat tidak mengetahui secara jelas standar operasional prosedur mengenai waktu dan persyaratan pelayanan sehingga membuat proses penyelesaiannya masih membutuhkan waktu yang lama, kemudian gejala lainnya seperti ketelitian dalam melakukan pelayanan kurang baik, terutama kelengkapan berkas yang sangat ingin dilayani terkadang salah penulisan sehingga pelayanan kembali diulang, hal tersebut disebabkan karena tingkat pendidikan pegawai yang tidak sejalan dengan keahlian dalam hal pemberian layanan.

Banyaknya aparat yang tidak sejalan dengam disiplin ilmunya, serta adanya aparat yang memiliki jabatan strategis yang berpendidikan SMA/Sederajat, hal tersebut disebabkan karna masih adanya aparat yang tidak mengetahui tugas pokok, hal tersebut disebabkan karenaa tingkat pendidikan formal dan keahlian masih rendah serta kemauan dan motivasi yang belum sejalan yang diharapkan yang pada akhirnya akan berimplikasi pada ketidakmampuan aparat secara umum untuk menjalankan tugass yang dibebankan oleh organisasi, salah satunya dalam penerbitan surat-surat, terkadang aparat yang susah ditemui pada saat berurusan dan masih banyaknya masyarakat yang kurang mengetahui persyaratan yang harus mereka penuhi sehingga terkadang menyulitkan bagi mereka pada saat berurusan, padahal seharusnya pelayanan publik membuat masyarakat merasa tertolong dan terpenuhi kebutuhannya, dan respon pegawai terhadap masyarakat yang berurusan kurang tepat, selain itu juga sedikitnya sosialisasi langsung oleh pegawai terhadap masyarakat. Terdapat pula kecenderungan bahwa pengetahuan terutama jika dilihat dari tingkat pendidikan yang dimiliki oleh aparat Kantor Desa Maddenra belum memberikan kontribusi yang maksimal dalam pelaksanaan pelayanannya. Hal tersebut menunjukkan bahwa tingkat kompetensi aparat masih perlu ditingkatkan, sebab kemampuan aparat untuk memahami pekerjaan tergantung dari pengetahuan yang dimiliki, sedangkan pengetahuan itu sendiri dapat dilihat dari tingkat pendidikan.

Ukuran rendahnya kompetensi aparat Desa Maddenra adalah kurangnya keahlian yang ada pada aparat, dimana keterampilan tersebut dapat diperoleh dari pendidikan dan pelatihan, baik yang bersifat teknis maupun fungsional, sehingga keahlian aparat/karyawan belum memberikan sumbangsih yang optimal dalam pelaksanaan tugas-tugasnya terutama dalam hal layanan yang optimal Kompetensi sumber daya manusia sangat berpengaruh terhadap kualitas pelayanan, karena pelayanan tidak bisa berjalan sesuai dengan yang diharapkan masyarakat dan tidak bisa efektif tanpa adanya kompetensi yang dimiliki oleh setiap Aparat Desa. Adapun indikator Kompetensi sumber daya manusia menurut Michael Amstrong (2010: 9-10) yaitu 1) Skill atau keahlian, 2) Kualitas Individu, dan 3) Knowledge atau pengetahuan. Sehingga penulis tertarik untuk meneliti terkait "Kompetensi Sumber Daya Manusia terhadap Kualitas Pelayanan Publik di Kantor Desa 
Maddenra Kecamatan Kulo Kabupaten Sidenreng Rappang" dengan tujuan untuk mengetahui Kompetensi Sumber Daya Manusia terhdap Kualitas Pelayanan Publik di Kantor Desa Maddenra dan untuk mengetahui Faktor-faktor yang memengaruhi Kompetensi Sumber Daya Manusia di Kantor Desa Maddenra.

Menurut Mitrani (Ardiana \& Brahmayanti, 2003) yakni sifat seseorang yang sendirinya berkenaan dengan pelaksanaan pekerjaan secara efektif. Perlu diyakini bahwa kekuatan sumber daya manusia itu terletak pada kemampuan kerjasama yang dimiliki dan kerjasama tersebut dapat menjadi kenyataan bilamana tingkat kepercayaan individu dalam kelompok dapat ditumbuhkan. Menurut Anwar Prabu Mangkunegara (2009: 40), kompetensi sumber daya manusia kompetensi yang berkenaan pada keterampilan, kemampuan serta pengetahuan dan karakteristik kepribadian yang memengaruhi langsung pada kinerja setiap individu. Michael Amstrong (Yunus, 2011), mengatakan bahwa kompetensi berarti Knowledge, skill dan kualitas individu untuk mencapai keberhasilan pekerjaannya. Kompetensi sumber daya manusia menurut Michael Amstrong (2010:910) yaitu :

1. Skill atau keahlian. Keahlian disini merupakan suatu keahlian dari seiap pegawai dalam menjalankan tugas serta kecakapannya dalam pemberian layanan.

2. Kualitas Individu. kinerja organisasi, serta bahkan perkembangannya berkaitan erat dengan kemampuan individu yang mengelola perusahaan atau organisasi.

3. Knowledge atau pengetahuan. Pengetahuan merupakan ilmu atau pengetahuan maupun pengalaman yang dimiliki setiap pegawai yang sesuai dengan bidangnya dalam hal pemberian pelayanan.

Dari uraian tersebut, Menurut Hutapea dan Nuriana (2010), kualitas sumber daya yang handal sangat dibutuhkan oleh sebuah organisasi karena manusia yang berkualitas, berintelektual, keterampilan serta memiliki fisik sehat sangat berpengaruh terhadap pada majumundurnya sebuah organisasi.

Moenir dalam Sellang (2016 : 91) Pelayanan Publik ini berarti kegiaatan yang dilakukan seseorang dengan landasan material melalui sistem, metode dan prosedur tertentu dengan usaha untuk memenuhi kepentingan orang lain. ZethamlParasuraman-Berry (Samad, 2016) ukuran kepuasan terletak pada lima dimensi kualitas layanan sesuai dengan apa yang dituntut oleh masyarakat. Kelima indikator tersebut adalah:

1. Tangibles (bukti fisik). Bukti fisik ini merupakan sebuah fasilitas yang ada di Perusahaan tersebut yang diperlihatkan serta digunakan untuk memenuhi kepuasan masyarakat.

2. Reability (keandalan). Keandalan ini berarti kemampuan setiap pegawai yang memberikan layanan yang akurat serta cermat dalam menyelesaikan suatu pekerjaan.

3. Responsiveness (daya tanggap). Daya tanggap ini berarti ketanggapan setiap karyawan atau ketanggapan setiap individu untuk dengan segera mengantisipasi keluhan serta kebutuhan pelanggan yang memerlukan layanan.

4. Assurance (jaminan). Jaminan berarti kemampuan setiap individu karyawan dalam memberikan jaminan pelayanan tepat waktu sehingga menjadikan para penerima layanan menjadi percaya untuk melakukan pelayanan.

5. Emphaty (perhatian). Perhatian di sini merupakan perhatian pribadi dari para karyawan berupa sikap ramah dan sopan serta sikap adil dan sikap menghargai masyarakat yang membutuhkan layanan sehingga membuat penerima layanan merasa dimengerti dan dipahami sejalan dengan mereka harapkan.

Faktor internal dan faktor eksternal (Ozutku dan Ozturkler) (Nurjamilah, 2016:24), adapun faktor-faktor tersebut yaitu:

1. Faktor Internal. Faktor internal merupakan kemampuan suatu organisasi dalam hal meningkatkan kemampuan pelayanan, kemampuan mengantisipasi keluhan pelanggan maupun kebutuhan pelanggan serta kemampuan meningkatkan penggunaan tekhnologi.
a. Misi dan Tujuan Organisasi
b. Strategi Pencapaian Tujuan
c. Sifat dnan Jenis Kegiatan Orgnisasi
d. Jenis Tekhnologi yang Digunakan

2. Faktor Eksternal. Faktor eksternal ini adalah peningkatan pelayanan berdasarkan pengaruh luar organisai seperti pemerintahan dalam mendukung peningkatan SDM, masyarakat yang dilibatkan dalam peningkatan layanan sserta pegawai yang melakukan pelatihan 
sesuai bidangnya untuk pengembangan tekhnologi demi terwujudnya egovernance.
a. Kebijakan Pemerintah
b. Sosial Budaya Masyarakat
c. Perkembangan IImu Pengetahuan dan Tekhnologi.

\section{B. METODE PENELITIAN}

Penelitian ini menggunakan tipe penelitian deskriptif kuantitatif, dengan metode ini diharapkan bisa memberikan gambaran secara cermat, jelas dan objektif mengenai masalah yang sedang diteliti. Populasi pada penelitian ini sebanyak 2.095 jiwa yang merupakan penduduk di Desa Maddenra. Jumlah sampel adalah 95 orang/masyarakat. Tehnik penarikan sampel yang digunakan yakni Nonprobability Sampling. Tehnik Pengumpulan data yang digunakan yaitu Observasi, Wawancara, Studi Pustaka, dan Kuesioner, Sedangkan tehnik analisis data yang digunakan yaitu statistik deskriptif dan dengan bantuan SPSS versi 21 untuk melakukan pengujian hipotesis. Hasil analisis berupa statistik deskriptif, uji kualitas (uji validitas validitas dan uji reliabilitas), analisis regresi linear sederhana dan uji hipotesis.

\section{HASIL DAN PEMBAHASAN}

1. Hasil penelitian Kompetensi Sumber Daya Manusia (X) a. Skill atau keahlian : 1) ketepatan waktu pegawai dalam melaksanakan tugasnya sebesar $62 \%, 2$ ) keahlian pegawai menggunakan komputer sebesar $56 \%$, 3) ketelitian pegawai dalam memberikan pelayanan sebesar $57 \%$, b. Kualitas Individu : 1) kemampuan setiap pegawai memberikan pelayanan yang tepat sebesar $58 \%$, c. Knowledge atau pengetahuan : 1) pengalaman pegawai dalam memberi pelayanan sebesar $58 \%$, 2) tingkat pengetahuan komputer yang dimiliki pegawai dalam pelayanan kepada masyarakat sebesar $58 \%$. Berdasarkan dari uraian tersebut, maka dapat disimpulkan bahwa Kompetensi Sumber Daya Manusia di Kantor Desa Maddenra berada pada Kategori Kurang Baik dengan Persentase $58.16 \%$.

2. Hasil Penelitian Kualitas Pelayanan Publik (Y) a. Tangibles (bukti fisik) : 1) kenyamanan ruang tunggu sebesar $58 \%$, 2) kemudahan proses pelayanan sebesar $61 \%$, 3) tingkat kedisiplinan pegawai sebesar $51 \%$, b. Reability (keandalan) : 1) tingkat kecermatan pegawai dalam memberi pelayanan sebesar $55 \%$, 2) standar pelayanan yang ada sebesar $54 \%$, c. Responsiveness (daya tanggap) : 1) tanggapan pegawai terhadap keluhan masyarakat sebesar $58 \%$, 2) tanggapan pegawai kepada masyarakat untuk dilayani sebesar $62 \%$, d. Assurance (jaminan) : 1) jaminan berupa pelayanan tepat waktu sebesar $59 \%$, 2) kepastian biaya yang sesuai sebesar $61 \%$, e. Emphaty (perhatian) : 1) sikap ramah yang dimiliki pegawai dalam memberikan pelayanan sebesar $63 \%$, 2) sikap sopan yang dimiliki pegawai dalam memberikan pelayanan sebesar $64 \%$, 3) sikap pegawai dengan tidak membeda-bedakan di dalam memberikan pelayanan sebesar $54 \%$, 4) sikap pegawai yang menghargai masyarakat dalam memberikan pelayanan sebesar $58 \%$. Berdasarkan dari uraian tersebut, maka dapat disimpulkan Kualitas Pelayanan Publik di Kantor Desa Maddenra berada pada kategori Kurang baik dengan persentase $58.30 \%$.

3. Hasil penelitian Faktor-faktor yang Memengaruhi Kompetensi Sumber Daya Manusia: a. Faktor Internal: 1) pegawai dalam peningkatan kemampuan pelayanan $58 \%$. 2) kemampuan pegawai dalam mengantisipasi keluhan masyarakat 59\%. 3) Peningkatan pegawai dalam penggunaan komputer $56 \%$. b. Faktor eksternal: 1) sikap pemerintahan terhadap dukungan sumber daya manusia $59 \%$. 2) Keterlibatan masyarakat dalam peningkatan pelayanan $57 \%$. 3) pelatihan pegawai untuk mendukung pengembangan tekhnologi $51 \%$. Berdasarkan uraian dari uraian tersebut, maka dapat disimpulkan bahwa Faktorfaktor yang Memengaruhi Kompetensi Sumber Daya Manusia di Kantor Desa Maddenra berada pada Kategori Kurang Baik dengan persentase $56.67 \%$

Berdasarkan output uji validitas item. Berdasarkan dari output di atas untuk menguji tingkat validitas data yakni diketahui bahwa 6 item pertanyaan dalam mengukur variabel Kompetensi Sumber Daya Manusia (X) dinyatakan valid dengan nilai Corrected itemtotal correltion lebih besar dari $>0,25,0,30$ (corrected item-total correlation $>0.25,0.30$ ), yaitu X1 : 0.299, X2:0.60, X3:0.586, X4:0.394, X5:0.578, X6:0.618. 
Berdasarkan output uji validitas item. Berdasarkan dari output di atas untuk menguji tingkat validitas data yakni diketahui bahwa 13 item pertanyaan dalam mengukur variabel Kualitas pelayanan Publik dinyatakan valid dengan nilai Corrected item-total correlation lebih besar dari $>0,25,0,30$ (corrected item-total correlation $>0.25,0.30$ ), yaitu Y1:0.556, Y2:0.456, Y3:0.591, Y4:0.562, Y5:0.540, Y6:0.392, Y7:0.436, Y8:0.427, Y9:0.443, Y10:0.420, Y11:0.409, Y12:0.591, Y13:0.545.

Berdasarkan output uji validitas item. Berdasarkan dari output di atas untuk menguji tingkat validitas data yakni diketahui bahwa 6 item pertanyaan dalam mengukur Faktor-faktor yang memengaruhi Kompetensi Sumber Daya Manusia dinyatakan valid dengan Nilai Corrected item-total correlation lebih besar dari $>0,25,0,30$ (corrected itemtotal correlation $>0.25,0.30$ ), yaitu $\mathrm{F} 1: 0.656$, F2:0.343, F3:0.673, F4:0.605, F5:0.685, $\mathrm{F} 6: 0.581$.

\section{Uji reliabilitas}

Berdasarkan tentang jumlah data yang valid untuk diproses dan data yang dikeluarkan, serta persentasenya. Diketahui bahwa data atau case yang valid jumlahnya 95 dengan persentase $100 \%$ dan tidak ada data yang dikeluarkan (exclude).

Output tersebut sdbagai hasil dari reliabilitas cronbach alpha. Berdasarkan output tabel reliability statistics di atas, kuesioner penelitian dalam mengukur varibel Kompetensi Sumber Daya Manusia (X) reliabel karena Cronbach Alpha yang diperoleh adalah sebesar 0.764 yang berarti lebih besar dari $0.60(0.764>0.60)$.

Output tersebut sebagai hasil dari dari analisis reliabilitas cronbach alpha.Berdasarkan output tabelreliability statistics di atas, kuesioner penelitian dalam mengukur variabel Kualitas Pelayanan Publik (Y) reliabel karena Cronbach Alpha yang diperoleh adalah sebesar 0.839 yang berarti lebih besar dari $0.60(0.839>0.60)$.

Output tersebut sdbagai hasil dari reliabilitas cronbach alpha. Berdasarkan output tabelreliability statistics di atas, kuesioner penelitian dalam mengukur Faktorfakor yang memengaruhi Kompetensi Sumber Daya Manusia reliabel karena Cronbach Alpha yang diperoleh adalah sebesar 0.822 yang berarti lebih besar dari $0.60(0.822>$ $0.60)$.

\section{Uji Asumsi Klasik}

Berdasarkan uji asumsi diketahui bahwa grafik normal P-P Plot hasil olah data, maka model regresi dalam penelitian ini memenuhi asumsi normalitas yaitu data menyebar di sekitr garis diagonal dan mengikuti arah garis diagonal, atau grafik histogramnya menunjukkan pola dsitribusi normal, maka regresi memenuhi asumsi normalitas.

\section{Regresi Linear Sederhana dan Pengujian Hipotesis}

Berdasarkan dari tabel Model Summary, pada bagian ini ditampilkan ni $\mathrm{R}=$ 0.715 dan koefisien Determination Rsquare atau $\left(R^{2}\right)$ nilai sebesar 0.511 (hasil dari pengkuadratan koefisienkorelasi atau (R) $0.715 \times 0.715=0.511 \times 100 \%=51.1 \%)$, sedangkan sisanya $(100 \%-51.1 \%=48.9 \%)$. Hal tersebut menunjukkan bahwa untuk mencari besar faktor Kompetensi Sumber Daya Manusia (X) terhadap Kualitas Pelayanan Publik $(Y)$ dengan ini nilai yang dicari yaitu $51,1 \%$.

Hasil uji ANOVA pada bagian ini ditampilkan hasil yang diperoleh yakni nilai $F$ $=97.126$ dengan tingkat probabilitas sig. 0.000 . Karena probabilitas $(0.000)$ yang lebih kecil dripada 0,05 , dari hasil tersebut berarti model regresi bisa digunakan untuk, memprediksi kompetensi Sumber daya Manusiaa. Untuk menguji kebenaran hipotesis dilakukan uji $F$. Untuk mengetahui bahwa pengaruh/Signifikan hal terrsebut dilihat dari lefel of signifikan $a=0,05$. Jika nilai signifikan lebih kecil dripada 0,05 , berarti Ha diterima dan Ho ditolak. Berdasarkan hasil olah pada tabel ANOVA, maka diketahui nilai Fhitung yang diperoleh sebesar 97.126 dengan tingkat signifikan $0.000(\mathrm{Sig}<0,05)$ yang berarti variabel Kompetensi Sumber Daya Manusia (X) mempunyai pengaruh/signifikan terhadap Kualitas Pelayanan Publik (Y), dari hasil tersebut berarti model regresi bisa digunakan untuk, memprediksi Kualitas Pelayanan Publik di Kantor Desa Maddenra kecamatan Kulo Kabpaten Sidenreng Rappang.

Berdasarkan tabel Coefficients hasil olah data, dari hasil tersebut berarti model regresi yang digunakan pada penelitian ini untuk mengukur pengaruh kompetensi SDM terhadap Kualitas Pelayanan Publik di Kantor Desa maddenra.

$$
Y=16.090+1.275 X
$$


Dari fungsi regresi di atas, maka dapat dijelaskan :

1. Apabila variabel Kompetensi SDM (X) berubah, maka kualitas pelayanan (Y) juga akan berubah. Tanda positif menunjukka perubahan yang seaeah. Apabila Kompetensi Sumber Daya Manusia meningkat, maka Kualitas Pelayanan Publik juga akan meningkat dengan koefisien regresi sebesar 1.275, dan sebaliknya, jika Kompetensi Sumber Daya Manusia menurun, maka Kualitas Pelayanan Publik juka akan menurun dengan koefisisen regresi sebesar 1.275

2. Nilai konstanta sebesar 16.090 menunjukkan bahwa, jika semua variabel konstan maka Kompetensi Sumber daya Manusia masih bersifat positif.

Uji statistik $t$ untuk menunjukka seberapa besar pengaruh satu variabel pnjelas/independen secara individual menerangkan variasi variabel dependen berdasarkan tabel coefficientshasil olah data SPSS, maka diketahui bahwa :

a. Nilai thitung variabel Kompetensi SDM 9.855 dengan tingkat signifikan 0.000

b. Hipotesis berdasarkan uji t dirumuskan secara statistic

$\mathrm{Ha}:$ Pyx $\neq 0$

$\mathrm{HO}:$ Pyx $\neq 0$

Hipotesis bentuk kalimat:

1. Ha : Kompetensi Sumber Daya manusia berpengaruh/signifikan terhadap Kualitas Pelayanan Publik di Kantor Desa Maddenra Kecamatan Kulo Kabupaten Sidenreng Rappang.

2. HO : Kompetensi Sumber Daya manusia tidak berpengaruh/signifikan terhadap Kualitas Pelayanan Publik di Kantor Desa Maddenra Kecamatan Kulo Kabupaten Sidenreng Rappang.

Pengambilan Keputusan :

1. Jika nilai $t$ hitung $\geq t$ tabel, maka $\mathrm{HO}$ ditolak dan Ha diterima, artinya signifikan

2. Jika nilai nilai t hitung $\leq$, maka $\mathrm{HO}$ diterima dan Ha ditolak, artinya tidak signifikan.

Tabel Coefficients diperoleh $\mathrm{t}$ hitung $=$ 9.855 prosedur mencari statistic tabel dengan kriteria

1. Tingkat signifikan $(a=0,05)$

2. $\mathrm{df}=$ Jumlah Responden -2 atau $9-2=93$

3. $\mathrm{t}$ tabel $=\mathrm{a} / 2 ; \mathrm{df}$

$$
=0,05 / 2 ; \mathrm{df}
$$$$
=0,025 ; 93
$$

Sehingga $\mathrm{t}$ tabel $=1,989$
Keputusan :

Ternyata nilai $\mathrm{t}$ hitung $>\mathrm{t}$ tabel atau $9.855>1.989$, maka $\mathrm{HO}$ ditolak dan $\mathrm{Ha}$ diterima, artinya signifikan. Jadi, Kompetensi Sumber Daya Manusia berpengaruh signifikan terhadp Kualitas pelayanan Publik di Kantor Desa Maddenra Kecamatan Kulo kabupaten Sidenreng Rappang.

\section{Pembahasan}

Berdasarkan pada keputusan yang telah dipaparkan tentang pengujian hipotesis dapat dijelaskan bahwa Ho ditolak dan $\mathrm{Ha}$ diterima dengan kata lain $\mathrm{t}$ hitung $>\mathrm{t}$ tabel $(9.855>1,989)$ artinya Signifikan. Dari data tersebut dapat dikatakan bahwa Kompetensi Sumber Daya Manusia berpengaruh signifikan terhadap Kualitas Pelayanan Publik di Kantor Desa Maddenra Kecamatan Kulo Kabupaten Sidenreng Rappang. Jika kompetensi yang dimiliki belum memberikan sumbangsih yang optimal maka akan mengurangi tingkat keberhasilan dalam pelaksanaan tugas-tugasnya terutama dalam hal pelayanan yang berkualitas. Hal ini sesuai dengan yang dikemukakan oleh Michael Amstrong (2010:9-10) bahwa kompetensi adalah knowledge, skill dan kualitas individu untuk mencapai kesuksesan pekerjaannya. Semakin baik kompetensi sumber daya manusia pemerintah desa yakni terkait keahlian, kualitas individu serta pengetahuan, maka semakin baik kualitas tata kelola pemerintah desa hal tersebut akan meningkatkan kualitas pelayanan serta meningkatkan kepercayaan masyarakat terhadap kinerja pemerintah desa dalam memnberikan layanan yang berkualitas.

Birokrasi pemerintahan dikatakan baik apabila memberikan pelayanan yang optimal kepada masyarakat. Untuk itu, Kompetensi sumber daya manusia yang baik akan mendukung kemampuan aparat dalam melaksanakan tugas untuk memberikan pelayanan yang optimal. Kompetensi yang dimiliki oleh aparat sebagai sumber daya manusia akan dipahami dengan jelas apabila disadari bahwa pencapaian tujuan organisasi sangat ditentukan oleh peranan sumber daya manusia dan kemauan setiap aparat untuk meningkatkan kompetensinya sehingga dalam hal melaksanakan pelayanan dapat dilaksanakan secara optimal. kualitas sumber daya yang handal sangat dibutuhkan oleh sebuah organisasi karena manusia yang 
berkualitas, berintelektual, keterampilan serta memiliki fisik sehat sangat berpengaruh terhadap pada majumundurnya sebuah organisasi.

Berdasarkan data distribusi frekuensi variabel kompetensi sumber daya manusia dapat dilihat bahwa tingkat capaian responden sebesar 58,16\%. Ini memperlihatkan bahwa nilai tingkat capaian responden berada pada kategori kurang baik maka dari itu kompetensi sumber daya manusia harus tetap ditingkatkan, utamanya sumber daya manusia yang dikelola agar dapat mengoptimalkan dan memaksimalkan kemampuan, kualitas serta pengetahuan individu. Hasil wawancara yang telah dilakukan pada hari Jumat tanggal 13 Maret 2020 dengan Kepala Desa Maddenra yang mengatakan bahwa: "ya, kami disini memang selalu mengupayakan mendorong pegawai agar mengoptimalkan peningkatan terkait pengetahuan serta kualitas individu sehingga pelayanan yang diberikan dapat maksimal". Sedangkan data disritbusi frekuensi variabel kualitas pelayanan publik dapat dilihat bahwa tingkat capaian responden yang diberikan adalah 58,30\% yang terdiri dari 5 indikator pelayanan publik yang dikemukakan oleh Zethaml parasuraman berry (Samad, 2016) yakni Bukti fisik, keandalan, daya tanggap, jaminan dan perhatian. Berdasarkan hasil analisis data tersebut diperoleh capaian responden sebesar $58,30 \%$ berada pada kategori kurang baik dikarenakan penerapan kompetensi yang dimiliki aparat dalam hal pemberian layanan masih dinilai belum memberikan sumbangsih yang optimal dalam pelaksanaan tugas-tugasnya terutama dalam hal pelayanan yang berkualitas dan hasil penelitian ini sejalan dengan penelitian penelitian sebelumnya yang dilakukan oleh Nurmasitha, dkk (2012) dengan judul Pengaruh Kompetensi Pegawai dan Lingkungan Kerja terhadap Kualitas Pelayanan yang menyatakan bahwa dengan adanya beberapa indikator dalam kompetensi, yaitu indikator motif, karakter pribadi, konsep diri, pengetahuan dan keterampilan, dimana beberapa indikator diatas merupakan faktor yang penting di dalam pembentukan kompetensi seseorang dalam suatu organisasi guna memberikan kualitas pelayanan kepada masyarakat, maka kualitas sumber daya yang handal sangat dibutuhkan oleh sebuah organisasi karena manusia yang berkualitas, berintelektual, keterampilan serta memiliki fisik sehat sangat berpengaruh pada kinerja organisasi dalam pelayanan kepada publik. Hasil wawancara yang telah dilakukan pada hari Jumat tanggal 13 Maret 2020 dengan Kepala Desa Maddenra yang mengatakan bahwa: "ya, mengenai peningkatan kompetensi pegawai terkait pelayanan yang berkualitas memang perlu adanya peningkatan dan kami disini selalu mengupayakan pelatihan-pelatihan, karena dengan adanya peningkatan kompetensi sumber daya manusia maka pelayanan juga akan meningkat".

Berdasarkan hal tersebut, maka kualitas pelayanan publik dikatakan optimal dan berkualitas apabila dalam melaksanakan kegiatan yang berhubungan dengan pelayanan, Kompetensi yang dimiliki oleh aparat sebagai sumber daya manusia akan dipahami dengan jelas apabila disadari bahwa pencapaian tujuan organisasi sangat ditentukan oleh peranan sumber daya manusia dan kemauan setiap aparat untuk meningkatkan kompetensinya, baik itu pemerintah desa mampu mengoptimalkan dan memaksimalkan kemampuan, kualitas serta pengetahuan individu sehingga dalam hal melaksanakan pelayanan dapat dilaksanakan secara optimal.

Berdasarkan data distribusi frekuensi faktor-faktor yang memengaruhi kompetensi sumber daya manusia dapat dilihat bahwa tingkat capaian responden sebesar $56,67 \%$ ini memperlihatkan capaian responden yang diberikan berada pada kategori kurang baik ini dikarenakan minimnya antusias pemerintah desa dalam peningkatan pengetahuan serta pelatihan dalam bidang kerjanya khususnya dalam pengembangan ilmu tekhnologi, dalam peningkatan pegawai yang berkompeten diperlukan adanya pengetahuan pelayanan dan pelatihan terutama penggunaan tekhnologi sehingga pegawai lebih berkompeten dalam memberikan pelayanan. Sesuai yang dikemukakan oleh (Ozutku dan Ozturkler) (Nurjamilah, 2016:24) yang mengatakan bahwa majumundurnya sebuah organisasi diperlukan adanya peningkatan pelayanan yang baik, perencanaan yang baik dan implementasinya secara tepat, untuk itu diperlukan kemampuan tenaga sumber daya manusia melalui pelatihan dan pengembangan sumber daya manusia. Hasil wawancara yang telah dilakukan pada hari Jumat tanggal 13 Maret 2020 dengan Kepala 
Desa Maddenra yang mengatakan bahwa: “ Menurut saya, memang pelatihan terkait kompetensi pegawai itu perlu dilakukan dan kami selalu mengupayakan hal itu, agar kompetensi pegawai dalam bidang pelayanan dapat maksimal".

\section{KESIMPULAN}

1. Hasil perhitungan SPSS yaitu $\mathrm{t}$ hitung $>\mathrm{t}$ tabel atau $9.855>1.989$ maka Ha diterima berarti signifikan, Kompetensi Sumber Daya Manusia berpengaruh signifikan terhdap Kualitas pelayanan Publik di Kantor Desa Maddenra dengan sumbangan persentase pengaruh sebesar $51,1 \%$. Apabila kompetensi sumber daya manusia dinilai kurang baik maka kualitas pelayanan juga kurang baik, maka akan mempengaruhi kualitas pelayanan serta kepercayaan masyarakat terhadap kinerja pemerintah desa dalam memberikan layanan. Kompetensi Sumber Daya Manusia (X) di Kantor Desa Maddenra berada pada kategori Kurang Baik dengan persentase $58.16 \%$. Kualitas pelayanan Publik (Y) di Kantor Desa Maddenra berada pada kategoru Kurang Baik dengan Persentase 58.30\%.

2. Hasil penelitian Faktor-faktor yang Memengaruhi Kompetensi Sumber Daya Manusia: a. Faktor Internal: 1) pegawai dalam peningkatan kemampuan pelayanan $58 \%$. 2) kemamppuan pegawai dalam mengantisipasi keluhan masyarakat $59 \%$. 3) Peningkatan pegawai dalam penggunaan komputer $56 \%$. b. Faktor eksternal: 1) sikap pemerintahan terhadap dukungan sumber daya manusia $59 \%$. 2) Keterlibatan masyarakat dalam peningkatan pelayanan $57 \%$. 3) pelatihan pegawai untk menduukung pengembangan tekhnologi $51 \%$. Berdasarkan dari uraian tersebut, maka disimpulkan bahwa Faktor-fakktor yang Memengruhi Kompetensi Sumber Daya Manusia di Kantor Desa Maddenra berada pada Kategori Kurang Baik dengan persentase $56.67 \%$, dikarenakan minimnya antusias pemerintah desa dalam peningkatan pengetahuan serta pelatihan dalam bidang kerjanya khususnya dalam pengembangan ilmu tekhnologi.

\section{E. REFERENSI}

Ahmad, Jamaluddin. 2015. Metode Penelitian Administrasi Publik Teori danAplikasinya. Yogyakarta : Gava Media.

Ghozali, Imam. 2009. Aplikasi Multivariate dengan program SPSS. Semarang : UNDIP.

Kamaruddin, S. (2016). Administrasi dan Pelayanan Publik antara Teori dan Aplikasinya. Yogyakarta: Ombak.

Mangkunegara, A.P. 2009. Manajemen Sumber Daya Manusia. Refika Aditama. Bandung.

Michael Amstrong. 2002. Manajemen Sumber Daya Manusia. Gramedia, Jakarta.

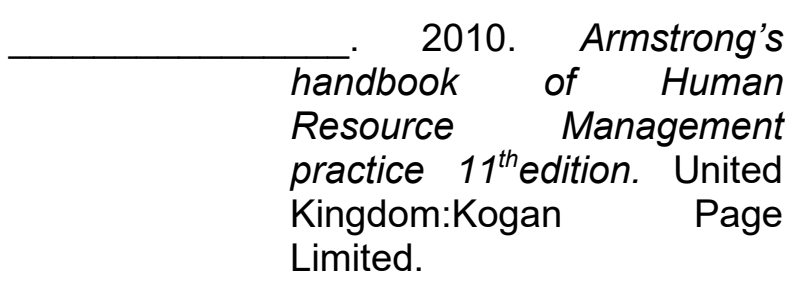

Nazir. 2005. Manajemen Kualitas Pelayanan. STIA LAN Press, Jakarta.

Nuriana, Hutapea. 2010. Manajemen Sumber Daya Manusia. Pustaka Pelajar, Yogyakarta.

Nurjamilah, Sayyidah. 2016. Human Resource Management practice and Organizational Innovation. Universitas Garut : Garut.

Samad, Zainuddin. 2016. Birokrasi dalam Pelayanan Publik. Yogyakarta : Ombak.

Sugiyono. 2013. Metode Penelitian Kuantitatif Kualitatif dan R\&D. Alfabeta. Bandung.

Sugiyono. 2015. Metode Penelitian Kombinasi. Cetakan Ke 7.Bandung : Alfabeta.

Yunus, E. (2011). Pengaruh Kompetensi SDM terhadap KInerja Pegawai KPPBC Tipe Madya Pabean Tanjubg perak Surabaya, 
(110), 368-387.

Dokumen-dokumen:

Peraturan Menteri Pandayagunaan Aparatur Negara dan Reformasi
Birokrasi Republik Indonesia (Permenpan) Nomor 15 tahun 2014 tentang pedoman Standar Pelayanan. 